\title{
Acromegaly with congenital generalized lipodystrophy - two rare insulin resistance conditions in one patient: a case report
}

Vanessa Guerreiro ${ }^{1,2,3^{*}}$, Irene Bernardes ${ }^{4}$, Josué Pereira ${ }^{5}$, Roberto Pestana Silva ${ }^{6}$, Susana Fernandes ${ }^{7}$, Davide Carvalho ${ }^{1,2,3}$ and Paula Freitas ${ }^{1,2,3}$

\begin{abstract}
Background: Lipodystrophies are a group of diseases which are characterized by abnormal adipose tissue deposition and are frequently associated with metabolic changes. Congenital generalized lipodystrophy is an autosomal recessive syndrome, with a prevalence $<1: 10$ million. Acromegaly is a rare disease, secondary to the chronic hypersecretion of growth hormone and insulin-like growth factor-1, with characteristic metabolic and somatic effects. "Acromegaloidism" is a term used for patients who manifest clinical features of acromegaly, but do not present a demonstrable hormone growth hypersecretion. The extreme shortage of subcutaneous adipose tissues and muscle hypertrophy confer an acromegaloid-like appearance in these patients.

Case presentation: We describe a case of a patient with the rare combination of Berardinelli-Seip congenital lipodystrophy and acromegaly; our patient is a 63-year-old white man, who was referred to an endocrinology consultation for suspected lipodystrophy. He had lipoatrophy of upper and lower limbs, trunk, and buttocks, with muscular prominence, acromegaloid facial appearance, large extremities, and soft tissue tumescence. In addition, he had dyslipidemia and prediabetes. His fat mass ratio (\% trunk fat mass/\% lower limbs fat mass) was 1.02 by densitometry and he also had hepatomegaly, with mild steatosis (from an abdominal ultrasound), and left ventricular hypertrophy (from an electrocardiogram). His first oral glucose tolerance test had growth hormone nadir of $0.92 \mathrm{ng} / \mathrm{mL}$, and the second test, 10 months afterwards, registered growth hormone nadir of $0.64 \mathrm{ng} / \mathrm{mL}$ (growth hormone nadir $<0.3 \mathrm{ng} / \mathrm{mL}$ excludes acromegaly). Pituitary magnetic resonance imaging identified an area of hypocaptation of contrast product in relation to a pituitary adenoma and he was subsequently submitted to transsphenoidal surgical resection of the mass. A pathological evaluation showed pituitary adenoma with extensive expression of growth hormone and adrenocorticotropic hormone, as well as a rare expression of follicle-stimulating hormone and prolactin.

A genetic study revealed an exon 3/exon 4 deletion of the AGPAT2 gene in homozygosity.
\end{abstract}

Conclusions: Congenital generalized lipodystrophy is a rare disease which occurs with acromegaloid features. As far as we know, we have described the first case of genetic lipodystrophy associated with true acromegaly. Although this is a rare association, the presence of congenital generalized lipodystrophy should not exclude the possibility of simultaneous acromegaly.

Keywords: Lipodystrophies, Acromegaly, IGF-1

\footnotetext{
* Correspondence: vanessa.a.guerreiro@gmail.com

${ }^{1}$ Department of Endocrinology, Diabetes and Metabolism, Centro Hospitalar

Universitário de São João EPE, Alameda Professor Hernâni Monteiro,

4202-451 Porto, Portugal

${ }^{2}$ Faculty of Medicine of the Universidade do Porto, Porto, Portugal

Full list of author information is available at the end of the article
}

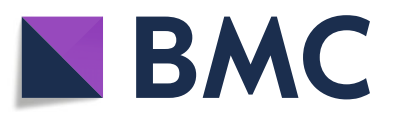

(c) The Author(s). 2020 Open Access This article is distributed under the terms of the Creative Commons Attribution 4.0 International License (http://creativecommons.org/licenses/by/4.0/), which permits unrestricted use, distribution, and

reproduction in any medium, provided you give appropriate credit to the original author(s) and the source, provide a link to the Creative Commons license, and indicate if changes were made. The Creative Commons Public Domain Dedication waiver (http://creativecommons.org/publicdomain/zero/1.0/) applies to the data made available in this article, unless otherwise stated. 


\section{Background}

Lipodystrophies are a group of genetic or acquired diseases characterized by abnormal adipose tissue deposition, including peripheral fat loss (lipoatrophy) and central fat accumulation (lipohypertrophy or abdominal prominence), which could be present separately or combined in the same individual [1-3]. These syndromes are usually, but not invariably, linked with severe metabolic complications, such as insulin resistance, diabetes, lipid abnormalities, hypertension, and hepatic steatosis [4]. Many complications of lipodystrophy are secondary to deficient adipose mass, resulting in ectopic lipid storage in the liver, muscles, and other organs, with associated insulin resistance [5].

Furthermore, the extremely low levels of leptin, resulting from subcutaneous adipose tissue loss, play an important role in the pathophysiology of the associated comorbilities [6].

Congenital generalized lipodystrophy (CGL) or Berardinelli-Seip congenital lipodystrophy (BSCL) is a well-defined syndrome which is characterized by a generalized absence of adipose tissue from birth or shortly after, as well as severe insulin resistance $[7,8]$. The condition is inherited as an autosomal recessive trait, which is often associated with parental consanguinity [9]. Several causative genetic mutations have been identified. There are at least four molecularly distinct forms where the variations of 1-acylglycerol3-phosphate $\mathrm{O}$-acyltransferase 2 (AGPAT2; BSCL type 1 ) and BSCL2 (BSCL type 2) are the most common variations [10]. However, in most cases, the diagnosis of lipodystrophy is based on family history, physical examination, body composition, and metabolic status, supplemented by confirmatory genetic testing, albeit only in certain forms [5, 8]. There are no defined serum leptin levels that establish or rule out the diagnosis of lipodystrophy.

The AGPAT2 protein belongs to the family of AGPATs. These enzymes are fundamental for the biosynthesis of glycerol-3-phosphate triglycerides and phospholipids. The protein is highly expressed in adipose tissue, and its deficiency can cause lipodystrophy by inhibiting/reducing the synthesis of triacylglycerols and its storage in adipocytes. It is likely that a low activity of AGPAT2 could also increase the tissue levels of lysophosphatidic acid, which, in turn, could affect the functions of adipocytes [3, 7, 11].

Ever since Berardinelli described a very rare case of generalized congenital lipodystrophy in a 2-year-old boy from Brazil in 1954 [12], nearly 400 cases [13] have been reported in the literature, with a prevalence $<1$ in 10 million [14].

With a prevalence of 38 to 80 cases per million, acromegaly is a rare disease. It is an insidious disease, which is secondary to the chronic hypersecretion of growth hormone (GH) and insulin-like growth factor-1 (IGF-1), with its characteristic metabolic and somatic effects. Most cases of acromegaly are caused by pituitary adenoma and the first-choice treatment of these cases is transsphenoidal surgery [15].

The extreme shortage of subcutaneous adipose tissue and other adipose tissues, and muscle hypertrophy, confer an acromegaloid-like appearance in patients with CGL [13]; however, no case of BSCL and true acromegaly has been reported in the literature to date.

\section{Case presentation}

A 63-year-old white man (Fig. 1), who was born from a consanguineous union (his parents were first cousins), was referred to our department for suspected lipodystrophy.

He experienced uncomplicated prenatal and postnatal periods, with normal developmental milestones.

His 59-year-old sister has a similar phenotype, and had generalized lipoatrophy since childhood, without diabetes or hypertension, and with normal IGF-1. A physical examination revealed that neither of the parents had lipodystrophic changes and neither had diabetes.

The results of our patient's physical examination were: weight $95.4 \mathrm{~kg}$; height $1.72 \mathrm{~m}$; body mass index (BMI) of $32.24 \mathrm{~kg} / \mathrm{m}^{2}$; waist circumference $91 \mathrm{~cm}$; blood pressure 119/75 mmHg; and near-total absence of subcutaneous fat on his upper and lower limbs, trunk, and buttocks, which is suggestive of generalized lipoatrophy. His facial appearance demonstrated a notable acromegaloid appearance, with thick lips, widening of the wings of the nose, creased nasolabial grooves, dental diastema, and prominence of the supra-ciliary arches, with slight prognathism. He also had muscular prominence, large hands and feet, and soft tissue tumescence, without acanthosis nigricans.

Biochemical tests (Table 1) revealed glycated hemoglobin (HbA1c) of 6.0\%; insulin resistance - homeostatic model assessment of insulin resistance (HOMA-IR) 9.6; total cholesterol $187 \mathrm{mg} / \mathrm{dL}$ (normal range $<200 \mathrm{mg} / \mathrm{dL}$ ); high-density lipoprotein (HDL) cholesterol $28 \mathrm{mg} / \mathrm{dL}$ (normal range $>60 \mathrm{mg} / \mathrm{dL}$ ); low-density lipoprotein (LDL) cholesterol $96 \mathrm{mg} / \mathrm{dL}$ (normal range $<100 \mathrm{mg} / \mathrm{dL}$ ); triglycerides $314 \mathrm{mg} / \mathrm{dL}$ (normal range $<150 \mathrm{mg} / \mathrm{dL}$ ); macroalbuminuria in spot urine with $382.5 \mathrm{mg} / \mathrm{g}$ creatinine (normal range $<30 \mathrm{mg} / \mathrm{dL}$ ); central hypothyroidism $(\mathrm{CH})$ with free thyroxine (FT4) $0.65 \mathrm{ng} / \mathrm{dL}$ (normal range $0.70-1.48 \mathrm{ng} / \mathrm{dL}) ;$ and thyroid-stimulating hormone (TSH) $1.10 \mu \mathrm{UI} / \mathrm{mL}$ (normal range 0.35-4.94 $\mu \mathrm{UI} / \mathrm{mL}$ ). There were increased IGF-1 values of $379-481 \mathrm{ng} / \mathrm{mL}$ (normal range $<269 \mathrm{mg} / \mathrm{dL}$ ). In the first oral glucose tolerance test (OGTT) (Table 2), our patient had impaired glucose tolerance $(101 \mathrm{mg} / \mathrm{dL}$ glucose at 0 minutes, and $186 \mathrm{mg} / \mathrm{dL}$ at 2 hours), with $\mathrm{GH}$ at 0 minutes of $1.5 \mathrm{ng} / \mathrm{mL}$ 


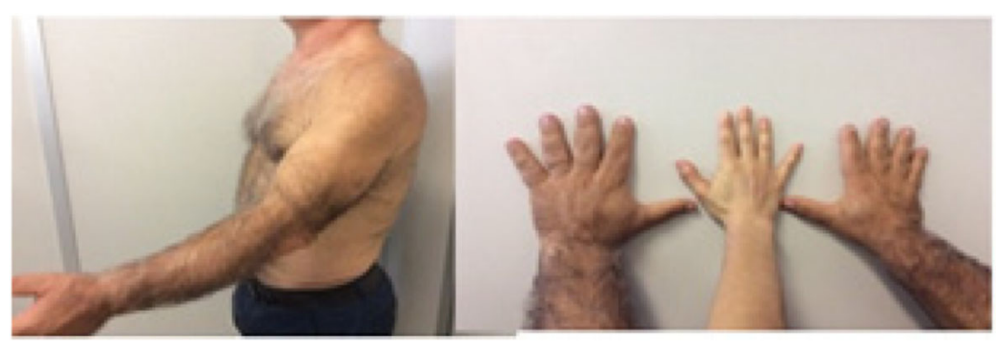

Fig. 1 Picture of the patient

and $0.92 \mathrm{ng} / \mathrm{mL}$ nadir (as we used an ultrasensitive assay IMMULITE $2000 \mathrm{hGH}$ - we could use a cut-off of a nadir serum $<0.3 \mathrm{ng} / \mathrm{mL}$ to exclude acromegaly [16]). As there was a high clinical suspicion of true acromegaly, we performed a second OGTT 10 months later (Table 3), which supported the diagnosis of diabetes (plasma glucose at 0 minutes of $120 \mathrm{mg} / \mathrm{dL}$, and $204 \mathrm{mg} / \mathrm{dL}$ at 2 hours), and

Table 1 Biochemical and hormonal parameters at diagnosis of acromegaly

\begin{tabular}{|c|c|c|}
\hline Parameter & Result & Normal range \\
\hline Fasting plasma glucose, mg/dL & 101 & $75-110$ \\
\hline Total cholesterol, mg/dL & 187 & $<200$ \\
\hline Triglycerides, mg/dL & 314 & $<150$ \\
\hline $\mathrm{HDL}, \mathrm{mg} / \mathrm{dL}$ & 28 & $>60$ \\
\hline Calculated LDL, mg/dL & 141 & $<130$ \\
\hline Urea, mg/dL & 51 & $10-50$ \\
\hline Creatinine, mg/dL & 0.87 & $0.67-1.17$ \\
\hline AST, U/L & 38 & $10-37$ \\
\hline $\mathrm{ALT}, \mathrm{U} / \mathrm{L}$ & 36 & $10-37$ \\
\hline GGT, U/L & 46 & $10-49$ \\
\hline IGF-1, nmol/L & 379 & $94-269$ \\
\hline $\mathrm{FT} 4, \mathrm{ng} / \mathrm{dL}$ & 0.65 & $0.70-1.48$ \\
\hline $\mathrm{TSH}, \mu \mathrm{UI} / \mathrm{mL}$ & 1.10 & $0.35-4.94$ \\
\hline $\mathrm{FSH}, \mathrm{mUl} / \mathrm{mL}$ & 3.98 & $1.50-12.4$ \\
\hline $\mathrm{LH}, \mathrm{mUI} / \mathrm{mL}$ & 5.48 & $1.70-8.60$ \\
\hline Total testosterone, ng/mL & 3.64 & 2.80.8.0 \\
\hline $\mathrm{SHBG}, \mathrm{nmol} / \mathrm{L}$ & 34.3 & $14.5-48.4$ \\
\hline Estradiol, pg/mL & 25.9 & $7.6-42.6$ \\
\hline Prolactin, ng/mL & 7.7 & $4.0-15.2$ \\
\hline Cortisol (a.m.), $\mu \mathrm{g} / \mathrm{dL}$ & 8.7 & $6.2-19.4$ \\
\hline ACTH (a.m.), ng/L & 26.9 & $<63.3$ \\
\hline $\mathrm{HbA} 1 \mathrm{c}, \%$ & 6.0 & $4.0-6.0$ \\
\hline Albuminuria, mg/L & 314.0 & $<30.0$ \\
\hline
\end{tabular}

ACTH adrenocorticotropic hormone, ALT alanine transaminase, AST aspartate transaminase, FSH follicle-stimulating hormone, FT4 free thyroxine, GGT gamma-glutamyltransferase, $H b A 1 c$ glycated hemoglobin, $H D L$ high-density lipoprotein, IGF-1 insulin-like growth factor-1, LDL low-density lipoprotein, LH luteinizing hormone, SHBG sex hormone-binding globulin, TSH thyroid-stimulating hormone confirmed the diagnosis of acromegaly (GH of $0.98 \mathrm{ng} / \mathrm{mL}$ at 0 minutes, and $0.64 \mathrm{ng} / \mathrm{mL}$ nadir).

Renal function, hepatic function, gonadal function, prolactin (PRL), morning adrenocorticotropic hormone (ACTH), and cortisol were all normal.

The fat mass ratio (FMR) by bone densitometry (\% trunk fat mass/\% lower limbs fat mass) was 1.02 (FMR in men $\geq 1.961$ discriminates lipodystrophy [16]), without signs of osteoporosis (lumbar spine $\mathrm{T}$ score +4.8 , $\mathrm{Z}$ score + 4.6; femur $\mathrm{T}$ score + 4.2, Z score + 4.7).

Total colonoscopy and upper digestive endoscopy were normal. Hepatosplenomegaly $(17 \mathrm{~cm})$ with mild fatty liver was observed in an abdominal ultrasound. In an electrocardiogram, left ventricular hypertrophy was observed; mild concentric left ventricular hypertrophy with mean ventricular ejection fraction of $67 \%$ was observed in an echocardiogram.

In the pituitary magnetic resonance imaging (MRI; Fig. 2), an area of hypocaptation of contrast product with rounded aspect in the right half of the pituitary gland was observed, passing the midline to the opposite side and invading the sphenoid sinus, in relation to the pituitary adenoma. There was no pituitary stalk deviation. As he presented a clinical picture of true acromegaly, he underwent transsphenoidal surgical resection of mass. A pathological evaluation (Fig. 3) showed pituitary adenoma, with extensive expression of $\mathrm{GH}$ and $\mathrm{ACTH}$, and rare expression of follicle-stimulating hormone (FSH) and PRL.

The genetics analyses of AGPAT2 by polymerase chain reaction (PCR) and Sanger sequencing revealed absence of amplification of exons 3 and 4. In order to clarify this fact, deletions/duplications located in the AGPAT2 gene

Table 2 First oral glucose tolerance test

\begin{tabular}{llll}
\hline OGTT $(1 \mathrm{st})$ & Glucose $(\mathrm{mg} / \mathrm{dL})$ & Insulin $(\mu \mathrm{U} / \mathrm{mL})$ & $\mathrm{GH}(\mathrm{ng} / \mathrm{mL})$ \\
\hline 0 minutes & 101 & 38.4 & 1.50 \\
30 minutes & 196 & 155.1 & 0.98 \\
60 minutes & 229 & 228.8 & 0.93 \\
90 minutes & 221 & 233.5 & 0.92 \\
120 minutes & 186 & 184.2 & 1.45
\end{tabular}

GH growth hormone, OGTT oral glucose tolerance test 
Table 3 Second oral glucose tolerance test, 10 months later

\begin{tabular}{llll}
\hline OGTT (2nd, 10 months) & Glucose $(\mathrm{mg} / \mathrm{dL})$ & Insulin $(\mu \mathrm{U} / \mathrm{mL})$ & $\mathrm{GH}(\mathrm{ng} / \mathrm{mL})$ \\
\hline 0 minutes & 120 & 40.3 & 0.98 \\
30 minutes & 239 & 176.8 & 0.69 \\
60 minutes & 290 & 138.9 & 0.73 \\
90 minutes & 266 & 231.9 & 0.65 \\
120 minutes & 204 & 102.3 & 0.64 \\
\hline
\end{tabular}

GH growth hormone, OGTT oral glucose tolerance test

(by quantitative PCR, using the PROBE Hs00085627AGPAT2 located at the transition intron 3/exon 3) demonstrated no amplification of the intron 3/exon 3 region for the AGPAT2 gene, which pointed to an exon 3/exon 4 deletion of the AGPAT2 gene in homozygosity, previously described $[17,18]$.

Our patient was prescribed a diet, exercise, lifestyle modification, metformin $700 \mathrm{mg}$ twice a day, atorvastatin $20 \mathrm{mg}$, and levothyroxine $75 \mu \mathrm{g}$ for diabetes, dyslipidemia, and $\mathrm{CH}$, respectively. Three months after pituitary surgery, his IGF-1 level of $172 \mathrm{ng} / \mathrm{mL}$ (51-187 ng/mL; Table 4) and OGTT (Table 5) were normal, with no other hormonal abnormalities, namely other pituitary hypofunction.

\section{Discussion}

This patient presented characteristics of generalized lipodystrophy, with lipoatrophy and associated metabolic consequences. As lipodystrophic phenotype had been present since birth, this led to the suspicion and diagnosis of CGL. Having identified AGPAT2 deletion,
BSCL type 1 was subsequently diagnosed. Although BSCL is generally recognized at birth, or shortly afterwards, as it is manifested by almost total body fat loss and prominent muscularity, which causes a serious and notable phenotype [10], in this particular case, our patient was only diagnosed as having the condition in adulthood. The delay in the diagnosis was probably due to the rarity of this clinical condition and the consequent lack of knowledge regarding it and the fact that there was an unusual absence of diabetes and dyslipidemia since puberty in this case. Our patient had many of the features of Berardinelli-Seip syndrome, such as: lipoatrophy affecting the trunk, limbs, and face; acromegaloid features; skeletal muscle hypertrophy; hypertriglyceridemia and insulin resistance; and hypertrophic cardiomyopathy and hepatomegaly secondary to hepatic steatosis [7]. The underlying etiology of cardiac abnormalities in lipodystrophy is still not clearly understood. Patients with CGL have severe insulin resistance, which may provide the context for the development of hypertrophic cardiomyopathy, given the effect of insulin on growth. Accumulation of triglycerides in the myocardium can also cause "lipotoxic cardiomyopathy"; however, there is no clear evidence that these patients have ectopic fat deposition in the myocardium [19]. In this particular patient, the presence of acromegaly may have contributed to both conditions (hypertrophic cardiomyopathy and hepatomegaly) [20].

The fact that our patient had normal TSH does not exclude $\mathrm{CH}$, as $84 \%$ of patients with $\mathrm{CH}$ have normal TSH values [21] and the combination of a low FT4 and a non-markedly elevated TSH in patients with known
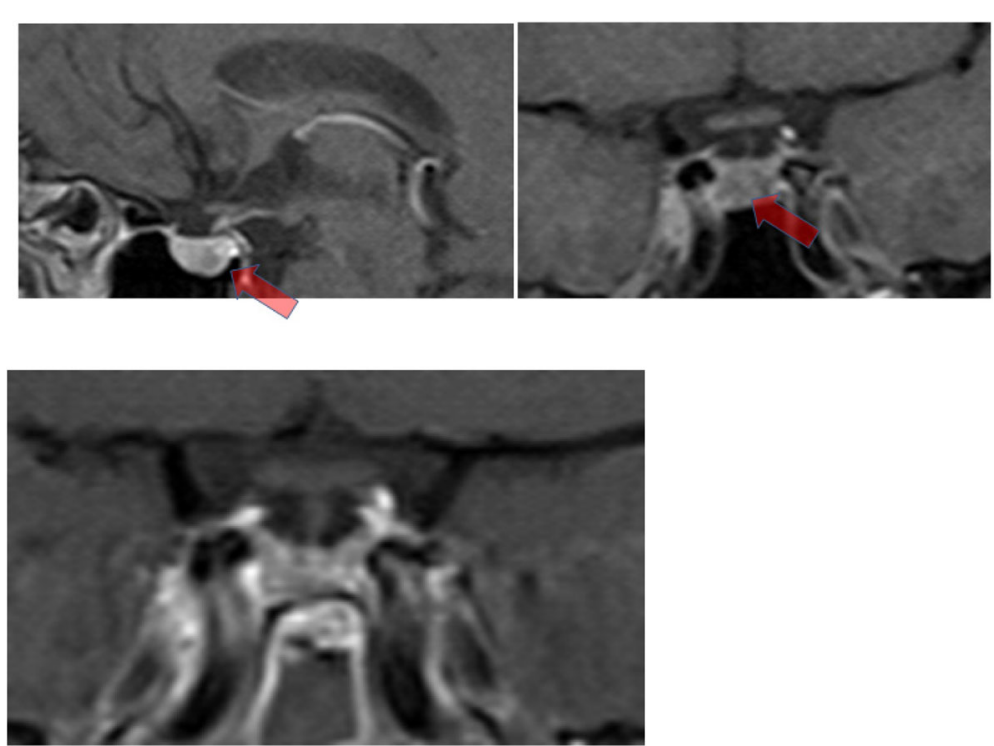

Fig. 2 Pituitary magnetic resonance imaging. Arrow: The most hypocaptizing (darkest gray) region, with rounded aspect, in the right half of the pituitary gland, passing the midline to the opposite side and prophesying to the sphenoid sinus in relation to the pituitary adenoma 


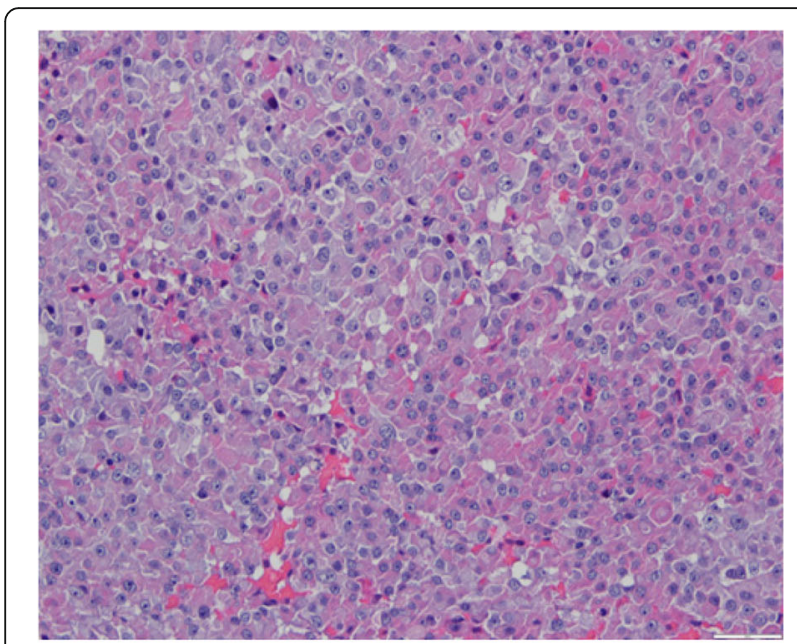

a

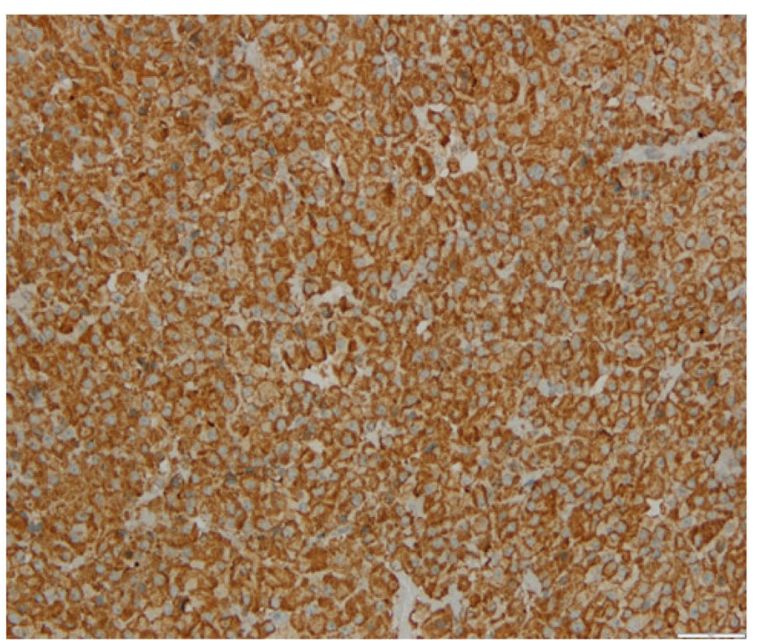

b

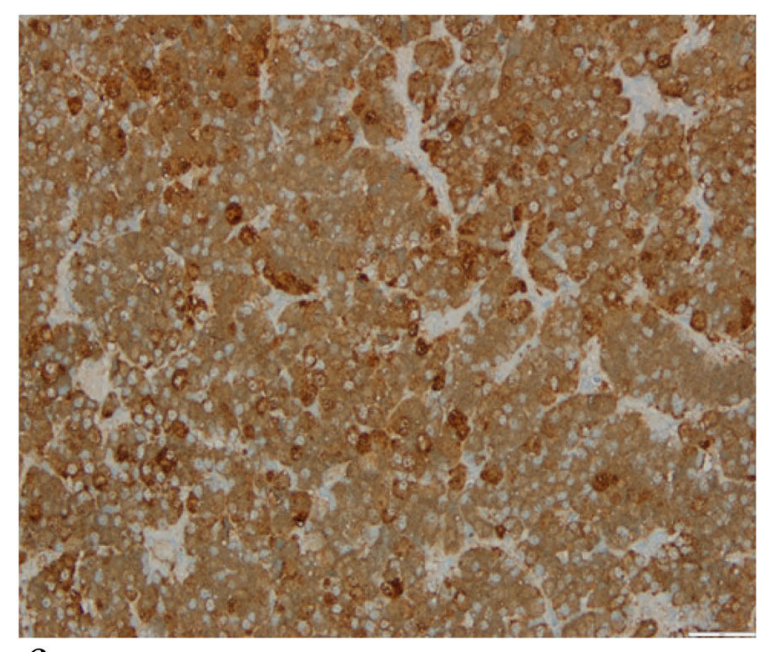

C

Fig. 3 Histological examination. Pituitary adenoma with areas of cells with eosinophilic or amphiphilic cytoplasm (a) with somatotropin expression (b), and in other areas, cells with broad amphiphilic and granular cytoplasm with adrenocorticotropic hormone expression (c)
Table 4 Hormonal parameters 3 months after pituitary surgery

\begin{tabular}{lll}
\hline Parameter & Result & Normal range \\
\hline $\mathrm{GH}, \mathrm{ng} / \mathrm{mL}$ & 2.34 & $<3.0$ \\
IGF-1, ng/mL & 172 & $51-187$ \\
IGFBP-3, $\mu \mathrm{g} / \mathrm{mL}$ & 5.7 & $3.2-6.9$ \\
\hline
\end{tabular}

GH somatotropin, IGF-1 insulin-like growth factor-1, IGFBP-3 insulin-like growth factor-binding protein 3

pituitary disease is a diagnostic of $\mathrm{CH}$, unless a patient is severely ill and is affected by non-thyroidal illnessinduced changes in the thyroid hormone [22]. Both CGL and acromegaly could explain this finding. We could speculate that leptin, which has a significant impact on the synthesis and release of the thyrotropin-releasing hormone and is a metabolic signal that modulates hypothalamic-pituitary-thyroid axis activity in animals and humans, could explain the $\mathrm{CH}$ as both lipodystrophy and acromegaly are associated with low levels of leptin [23].

The mechanism underlying acromegaloid characteristics in lipodystrophies is not yet fully understood, although varied abnormalities in GH levels were reported. Uncontrolled diabetes leads to liver resistance to $\mathrm{GH}$, with decreased hepatic IGF-I production. The lack of negative feedback effect of IGF-I on GH secretion causes $\mathrm{GH}$ hypersecretion, which partially explains the elevated $\mathrm{GH}$ level observed in some of these patients; however, this is not the case here, as HbAlc was controlled in our patient [24, 25]. Our patient presented acromegaloid characteristics, as well as acromegaly confirmed in histology [15]. The acromegaloid phenotype can be present in patients with CGL without acromegaly; however, in this case, the very marked acromegaloid features associated with a high degree of clinical suspicion of a true acromegaly and the duplications of IGF-1 levels (which are not usually common in CGL) led to the need to repeat the laboratorial evaluation. Even though Endocrine Society guidelines point out that with more sensitive new assays used for $\mathrm{GH}$ determination, a nadir of $\mathrm{GH}$ serum $<0.4 \mathrm{ng} / \mathrm{mL}$ after an orally administered glucose load could be used to exclude acromegaly, they suggest that it is sufficient to use the cut-off value $<1 \mathrm{ng} / \mathrm{mL}$ after an orally administered glucose load to exclude this

Table 5 Oral glucose tolerance test 3 months after pituitary surgery

\begin{tabular}{llll}
\hline OGTT & Glucose $(\mathrm{mg} / \mathrm{dL})$ & Insulin $(\mu \mathrm{U} / \mathrm{mL})$ & $\mathrm{GH}(\mathrm{ng} / \mathrm{mL})$ \\
\hline 0 minutes & 90 & 21.6 & 0.24 \\
30 minutes & 213 & 161.1 & 0.09 \\
60 minutes & 258 & 284.2 & 0.08 \\
90 minutes & 212 & 185.0 & 0.06 \\
120 minutes & 141 & 97.7 & 0.39
\end{tabular}

GH growth hormone, OGGT oral glucose tolerance test 
disease. If we used the cut-off of $1 \mathrm{ng} / \mathrm{mL}$, as suggested, our patient would have IGF-1/GH discrepancy [12]. New data even suggest a cut-off of $<0.3 \mathrm{ng} / \mathrm{mL}$ to exclude this disease [16]. When a discrepancy of GH/IGF-1 value is found during a diagnosis, we should really pursue close follow-up [26]. Normal GH suppression [12] with high IGF-1is not so uncommon nowadays. In a recent series report, $31 \%$ of 157 treatment-naive patients with acromegaly had elevated IGF-1 and normal 24 hours mean plasma GH levels. The percentage of GH/IGF-1 discrepancy has increased to $47 \%$ in more recent years [27]. Newer GH assays, which are based on monoclonal antibodies with higher specificity, tend to be more sensitive when compared with older polyclonal antisera. Following an assay-adjusted cut-off, we confirmed the diagnosis. Furthermore, the pituitary MRI and later histological examination confirmed the presence of an adenoma, with extensive GH expression. From this case we have learned that we should expect GH cut-offs of normality according to the assay we use, particularly when we use ultrasensitive assays [25]. More, we learned that, although this is a rare association, the presence of CGL should not exclude the possibility of simultaneous acromegaly.

\section{Conclusion}

This case of CGL type 1 (AGPAT2 deletions) with true acromegaly is the first to be reported in the literature. The diagnosis of acromegaly was challenging due to the GH/IGF-1 discrepancy, which was surpassed by the use of a cut-off which was adjusted to the assay. Although this is a rare association, the presence of CGL should not exclude the possibility of simultaneous acromegaly.

\begin{abstract}
Abbreviations
ACTH: Adrenocorticotropic hormone; AGPAT2: 1-acylglycerol-3-phosphate Oacyltransferase 2; BMI: Body mass index; BSCL: Berardinelli-Seip congenital lipodystrophy; CGL: Congenital generalized lipodystrophy; $\mathrm{CH}$ : Central hypothyroidism; FMR: Fat mass ratio; FSH: Follicle-stimulating hormone; FT4: Free thyroxine; GH: Growth hormone; HbA1c: Glycated hemoglobin; HDL: High-density lipoprotein; HOMA-IR: Homeostatic model assessment of insulin resistance; IGF-1: Insulin-like growth factor-1; LDL: Low-density lipoprotein; MRI: Magnetic resonance imaging; OGTT: Oral glucose tolerance test; PCR: Polymerase chain reaction; PRL: Prolactin; TSH: Thyroid-stimulating hormone
\end{abstract}

\section{Acknowledgements}

Not applicable.

\section{Authors' contributions}

VG collected the data and drafted the manuscript, IB performed the radiological diagnosis, and reviewed the pictures and the paper, JP performed transsphenoidal surgery and reviewed the paper, RPS performed the anatomopathological diagnosis and reviewed the paper, SF performed the genetic diagnosis and reviewed the paper; DC judiciously reviewed the manuscript, PF performed the clinical diagnosis, followed the patient, and co-drafted the manuscript. All the authors approved the final manuscript.

\section{Funding}

We declare that no funding has been received for this study.

\section{Availability of data and materials}

The datasets generated during and/or analyzed during the current study are available from the corresponding author on reasonable request.

\section{Ethics approval and consent to participate}

All procedures performed in studies involving human participants were in accordance with the ethical standards of the national guidelines.

\section{Consent for publication}

Written informed consent was obtained from the patient for publication of this case report and any accompanying images. A copy of the written consent is available for review by the Editor-in-Chief of this journal.

\section{Competing interests}

The authors declare that they have no competing interests.

\section{Author details}

'Department of Endocrinology, Diabetes and Metabolism, Centro Hospitalar Universitário de São João EPE, Alameda Professor Hernâni Monteiro, 4202-451 Porto, Portugal. ${ }^{2}$ Faculty of Medicine of the Universidade do Porto, Porto, Portugal. ${ }^{3}$ Instituto de Investigação e Inovação em Saúde, Universidade do Porto, Porto, Portugal. ${ }^{4}$ Department of Neuroradiology, Centro Hospitalar Universitário de São João, Porto, Portugal. ${ }^{5}$ Department of Neurosurgery, Centro Hospitalar Universitário de São João, Porto, Portugal.

${ }^{6}$ Department of Pathology, Centro Hospitalar Universitário de São João, Porto, Portugal. ${ }^{7}$ Department of Genetics, Faculty of Medicine, Universidade do Porto, Porto, Portugal.

Received: 21 February 2019 Accepted: 20 January 2020 Published online: 21 February 2020

\section{References}

1. Carr A, Samaras K, Burton S, et al. A syndrome of peripheral lipodystrophy, hyperlipidaemia and insulin resistance in patients receiving HIV protease inhibitors. AIDS. 1998:12:F51-8.

2. Carr A, Miller J, Law M, Cooper DA. A syndrome of lipoatrophy, lactic acidaemia and liver dysfunction associated with HIV nucleoside analogue therapy: contribution to protease inhibitor-related lipodystrophy syndrome. AIDS. 2000;14:F25-32.

3. Freitas $P$ et al. Lipodystrophy: Beyond generalization? Article in Panminerva medica. 2013

4. Vatier C, Bidault G, Briand N, Guénantin AC, Teyssières L, Lascols O, Capeau J, Vigouroux $C$. What the genetics of lipodystrophy can teach us about insulin resistance and diabetes. Curr Diab Rep. 2013:13(6):757-67.

5. Brown $\mathrm{R}$, et al. The diagnosis and management of lipodystrophy syndromes: a multi-society practice guideline. J Clin Endocrinol Metab. 2016;101(12): 4500-11.

6. Haque W, Shimomura I, Matsuzawa $Y$, et al. Serum adiponectin and leptin levels in patients with lipodystrophies. J Clin Endocrinol Metab. 2002:87:2395-8.

7. Van Maldergem L. Berardinelli-Seip Congenital Lipodystrophy. 2003 Sep 8 [Updated 2012 Jun 28]. In: Pagon RA, Adam MP, Ardinger HH, et al., editors. GeneReviews ${ }^{\circledast}$ [Internet]. Available from: Google Scholar.

8. Bindlish $\mathrm{S}$, et al. Lipodystrophy: syndrome of severe insulin resistance. Colchester: Informa UK Ltd; 2015.

9. Magré J, Delépine $M$, Khallouf $E$, et al. Identification of the gene altered in Berardinelli-Seip congenital lipodystrophy on chromosome 11q13. Nat Genet. 2001;28:365.

10. Garg A. Clinical review: Lipodystrophies: genetic and acquired body fat disorders. J Clin Endocrinol Metab. 2011;96:3313-25.

11. Agarwal AK, Garg A. Congenital generalized lipodystrophy: significance of triglyceride biosynthetic pathways. Trends Endocrinol Metab. 2003;14:214-21.

12. Katznelson L, et al. Acromegaly: an endocrine society clinical practice guideline. J Clin Endocrinol Metab. 2014;99(11):3933-51.

13. Patni N. Congenital generalized lipodystrophies--new insights into metabolic dysfunction. Nat Rev Endocrinol. 2015;11(9):522-34.

14. Garg A. Acquired and inherited lipodystrophies. N Engl J Med. 2004;350: 1220-34.

15. Melmed S, Kleinberg D. Pituitary masses and tumors. In: Melmed S, Polonsky KS, Reed Larsen P, Kronenberg HM, editors. Williams textbook of endocrinology. 13th ed. Amsterdam: Elsevier; 2016. p. 232-99. 
16. Colao A, Grasso LFS, Giustina A, Melmed S, Chanson P, Pereira AM, et al. Author correction: acromegaly. Nat Rev Dis Primers. 2019;5(1):72.

17. Agarwal AK, Arioglu E, De Almeida S, Akkoc N, Taylor SI, Bowcock AM, et al. AGPAT2 is mutated in congenital generalized lipodystrophy linked to chromosome 9q34. Nat Genet. 2002;31(1):21-3.

18. Magré J, Delépine $M$, Van Maldergem L, Robert JJ, Maassen JA, Meier $M$, et al. Prevalence of mutations in AGPAT2 among human lipodystrophies. Diabetes. 2003;52(6):1573.

19. Freitas $P$, et al. Fat mass ratio: an objective tool to define lipodystrophy in hiv-infected patients under antiretroviral therapy. J Clin Densitom. 2010; 13(2):197-203.

20. Lupsa B, et al. Cardiomyopathy in congenital and acquired generalized lipodystrophy. Medicine (Baltimore). 2010;89(4):245-50

21. Alexopoulou, Beguin C, De Nayer P, Maiter D, et al. Clinical and hormonal characteristics of central hypothyroidism at diagnosis and during follow-up in adult patients. Eur J Endocrinol. 2004;150:1.

22. Fleseriu $\mathrm{M}$, et al. Hormonal replacement in hypopituitarism in adults: an endocrine society clinical practice guideline. J Clin Endocrinol Metab. 2016; 101(11):3888-921.

23. Dabrowska A, et al. Thyroid diseases in patients with acromegaly. Arch Med Sci. 2014;10:837-45.

24. Douyon L, Schteingart DE. Effect of obesity and starvation on thyroid hormone, growth hormone, and cortisol secretion. Endocrinol Metab Clin North Am. 2002:31:173-89.

25. Bereket $\mathrm{A}$, Lang $\mathrm{CH}$, Wilson TA. Alterations in the growth hormone-insulinlike growth factor axis in insulin dependent diabetes mellitus. Horm Metab Red. 1999;31:172-81.

26. Schilbach, $\mathrm{K}$, Strasburger $\mathrm{CJ}$; Bidlingmaier M. Biochemical investigations in diagnosis and follow up of acromegaly. Pituitary 2017; 20:33-45.

27. Butz LB, Sullivan SE, Chandler WF, Barkan AL. "Micromegaly": an update on the prevalence of acromegaly with apparently normal $\mathrm{GH}$ secretion in the modern era. Pituitary. 2016;19:547-51.

\section{Publisher's Note}

Springer Nature remains neutral with regard to jurisdictional claims in published maps and institutional affiliations.

Ready to submit your research? Choose BMC and benefit from:

- fast, convenient online submission

- thorough peer review by experienced researchers in your field

- rapid publication on acceptance

- support for research data, including large and complex data types

- gold Open Access which fosters wider collaboration and increased citations

- maximum visibility for your research: over $100 \mathrm{M}$ website views per year

At $\mathrm{BMC}$, research is always in progress.

Learn more biomedcentral.com/submissions 